\title{
HUBUNGAN INSENTIF PENJUALAN DENGAN MOTIVASI KERJA KARYAWAN PADA CV. ROLYA MOTOR DI BANDAR LAMPUNG
}

\author{
Husna Purnama ${ }^{(1)}$, Khairul Saleh ${ }^{(2)}$ \\ Fakultas Ekonomi Universitas Sang Bumi Ruwa Jurai \\ husnapurnama@fe.saburai.ac.id, kahirul1@fe.saburai.ac.id
}

\begin{abstract}
Abstrak. Hasil penelitian dapat disimpulkan sebagai berikut: Nilai $\mathrm{t}_{\text {hitung variabel strategi proses rekruitmen }}$ yaitu 10.812 dengan konstanta 1.996 pada $t$ tabel dengan db 76 dan taraf signifikan 0,05 diperoleh 1.665 karena $t_{\text {hitung }}>\mathrm{t}_{\text {tabel }}$ atau $10.812>1.655$ maka Ha diterima. Signifikasi variabel proses rekruitmen adalah 0.000 yang berarti probabilitas 0.00 , karena probabilitas kurang dari 0,05 maka Ha diterima. artinya proses rekruitmen berpengaruh positif terhadap kinerja PT. Andesit Lumbung Sejahtera Lampung. hubungan antara proses rekruitmen dengan kinerja sebesar 0,783 berada pada taraf sedang. Sedangkan kontribusi ( $R$ Square) proses rekruitmen terhadap peningkatan kinerja sebesar 0.612 artinya sebesar $61,2 \%$ variasi perubahan proses rekruitmen mampu dijelaskan oleh variabel kinerja sedangkan sisanya sebesar 38,8\% lagi dijelaskan oleh variabel lain diluar dari variabel penelitian ini. Berdasarkan hasil pengujian hipotesis ini maka proses rekruitmen berpengaruh positif dan signifikan terhadap kinerja PT. Andesit Lumbung Sejahtera Lampung.
\end{abstract}

Kata kunci: Motivasi, Pegawai, dan Kinerja.

\section{PENDAHULUAN}

Dalam rangka mencapai tujuan perusahaan, tentunya karyawan haruslah dibimbing dan diarahkan agar mempunyai loyalitas yang tinggi, mempunyai semangat kerja dan sebagainya. Pemimpin harus memberikan motivasi kepada karyawannya agar produktivitas kerja mereka meningkat demi tercapainya tujuan perusahaan. Hal ini disebabkan keinginan atau kepuasan karyawan berbeda satu dengan yang lainnya. Memotivasi karyawan untuk melakukan pekerjaan dengan giat dan tekun terkadang perlu juga dengan bentuk yang lain seperti penghargaan, rasa aman dan sebagainya cara demikianlah disebut dengan insentif.

Beranjak dari semakin terpuruknya perekonomian Indonesia pada saat ini, kita diharapkan pada krisis moneter yang kemudian berlanjut menjadi krisis ekonomi, dimana sejak tahun 1997 hingga sekarang belum menunjukkan tanda-tanda akan kepulihan.

Seiring dengan hal tersebut diatas, kita juga dihadapi dengan era globalisasi yang menuju kearah pasar bebas. Tentunya dalam keadaan siap maupun tidak siap kita akan menghadapinya. Dalam menyongsing era tersebut tentunya sumber daya manusia sangat memegang peranan yang sangat penting. Untuk itu setiap perusahaan baik industri maupun jasa harus mempersiapkan sumber daya manusia yang profesional handal serta mampu bersaing dengan karyawan perusahaan lainnya baik dari dalam maupun luar negeri. Hal itu harus didukung oleh sarana dan prasarana yang memadai seperti pemanfaatan teknologi, modal dan tak kalah penting adalah sumber daya manusia yang ada sangat memegang peranan yang sangat penting sehingga tercapainya tujuan perusahaan yang telah ditetapkan.

Karyawan yang sering menjadi ujung tombak dalam maju mundurnya suatu perusahaan bahkan menjadi simbol dari bonafit atau tidaknya suatu perusahaan.

Menurut Wahjo Sumidjo (2013 : 177), motivasi adalah dorongan kerja yang timbul pada diri seseorang untuk berperilaku dalam mencapai tujuan yang telah ditentukan.

Upaya pemenuhan kebutuhan akan sumber daya manusia, perusahaan melakukan kegiatan rekruitmen. Rekruitmen adalah proses pencarian dan "pemikatan" para calon karyawan (pelamar) 
yang mampu untuk melamar sebagai karyawan (Handoko, 2014:69). Menurut Hasibuan dalam Nur Kholid (2017: 1) rekruitmen karyawan merupakan langkah pertama dan yang mencerminkan berhasil tidaknya suatu perusahaan mencapai tujuan. Kegiatan perekruitan merupakan aspek yang paling penting dari fungsi pengadaan dan pengembangan sumber daya manusia. Perekruitan tidak berarti hanya memasukkan kedalam perusahaan sejumlah orang yang diperlukan, melainkan juga berkaitan dengan upaya mengukur kualitas pribadi calon karyawan. Merupakan sebuah kewajiban dalam sebuah organisasi dan perusahaan harus melakukan penyaringan untuk anggota atau para pekerja yang baru. Dengan rekruitmen yang tepat maka perusahaan dapat bertahan dalam menghadapi lingkungan yang serba dinamis.

Menurut Malthis, dkk., (Nur Kholid, 2017:8) kinerja (Performance) pada dasarnya adalah apa yang dilakukan atau tidak dilakukan oleh karyawan. Kinerja tidak menyangkut mengenai hasil dari perilaku karyawan, tetapi hanya pada perilaku itu sendiri. Kinerja yaitu perilaku atau apa yang karyawan lakukan, bukan mengenai apa yang karyawan hasilkan atau hasil dari kerja mereka. Kinerja seorang karyawan akan baik, jika seorang karyawan mempunyai kemampuan, pengetahuan, dan pendidikan yang baik dan disertai dengan penempatan karyawan berdasarkan kemampuan yang dimilikinya.

Pengelolaan sumber daya manusia yang baik dan tepat sangat diperlukan agar kinerja karyawan semain baik dalam melakukan pekerjaanya. Tujuan dari hal tersebut adalah untuk memberikan kepada organisasi satuan kerja yang efektif untuk mencapai tujuan studi tentang manajemen perusahaan, bagaimana seharusnya perusahaan dapat mengembangkan, menggunakan dan memelihara karyawan dalam kualitas dan kuantitas yang tetap.
Oleh karena itu pihak manajemen perusahaan harus mampu memahami bagaimana cara terbaik dalam mengelola karyawan yang berasal dari latar belakang, keahlian, dan kemampuan yang berbedabeda sehingga karyawan dapat bekerja sesuai dengan keahlian dan jenis pekerjaan yang diberikan.

Berdasarkan pra penelitian yang dilakukan penulis ditemukan permasalahan yang berkaitan dengan kinerja perusahaan. Permasalahan itu diantaranya adalah proses rekruitmen karyawan, karyawan yang telah direkrut dan diseleksi belum mampu menguasai peralatan yang digunakan dalam operasi perusahaan yang berdampak pada menurunya produktivitas kerja perusahaan. Fenomena lain yang ditemukan berupa proses rekruiment dan proses seleksi masih bersifat tertutup. Artinya bahwa dalam proses rekruitmen karyawan dan seleksi karyawan belum menggunakan standar kompetensi dalam penempatan karyawan sehingga banyak karyawan yang bekerja belum sesuai dengan kompetensi yang dimiliki yang berakibat pada kecelakaan kerja.

Berdasarkan uraian-uraian tersebut maka penulis tertarik untuk menulis judul : "Hubungan Insentif Penjualan Dengan Motivasi Kerja Karyawan Pada CV. Rolya Motor di Bandar Lampung”.

\section{KAJIAN TEORI}

\section{Rekruitmen}

Rekruitmen merupakan suatu keputusan perencanaan manajemen sumber daya manusia mengenai jumlah karyawan yang dibutuhkan, kapan diperlukan, serta kriteria apa saja yang diperlukan dalam suatu organisasi. Rekruitmen pada dasarnya merupakan usaha untuk mengisi jabatan atau pekerjaan yang kosong di lingkungan suatu organisasi atau perusahaan, untuk itu terdapat dua sumber sumber tenaga kerja 
yakni sumber dari luar (eksternal) organisasi atau dari dalam (internal) organisasi. Penarikkan (rekruitmen) pegawai merupakan suatu proses atau tindakan yang dilakukan oleh organisasi untuk mendapatkan tambahan pegawai melalui beberapa tahapan yang mencakup identifikasi dan evaluasi sumber-sumber penarikkan tenaga kerja, menentukan kebutuhan tenaga kerja, proses seleksi, penempatan, dan orientasi tenaga kerja.

\section{Menurut Sunyoto}

penarikkan tenaga kerja merupakan proses pemuatan dan penarikkan para pelamar yang tertarik dan memiliki kualifikasi terhadap lowongan yang dibutuhkan. Rekruitmen yang efektif memerlukan tersedianya informasi yang akurat dan berkesinambungan mengenai jumlah dan kualifikasi individu yang diperlukan untuk melaksanakan berbagai pekerjaan dalam organisasi.

Aktivitas rekruitmen akan menyisihkan pelamar yang kurang tepat dan memfokuskan upayanya pada calon yang akan dipanggil kembali. Aktivitas rekruitmen dapat membangun opini publik yang menguntungkan dengan cara mempengaruhi sikap para pelamar sedemikian rupa terlepas mereka diangkat atau tidak.

Hasibuan (2008:40) menyatakan bahwa rekruitmen merupakan usaha mencari dan mempengaruhi tenaga kerja, agar mau melamar lowongan pekerjaan yang ada dalam suatu organisasi. Aktivitas rekruitmen dimulai pada saat calon mulai dicari, dan berakhir pada saat lamaran mereka diserahkan. Handoko (2008:69) menjelaskan bahwa rekruitmen merupakan proses pencarian dan "pemikatan" para calon karyawan (pelamar) yang mampu untuk melamar sebagai karyawan. Indikator proses rekruitmen meliputi:

\section{Landasan Dasar Rekruitmen}

Menurut Hasibuan (2008:41), dasar penarikkan calon karyawan harus ditetapkan lebih dahulu supaya para pelamar yang akan memasukkan lamarannya sesuai dengan pekerjaan atau jabatan yang diminatinya. Dasar penarikkan harus berpedoman pada spesifikasi pekerjaan yang telah ditentukan untuk menduduki jabatan tersebut. Job Specification harus diuraikan secara terperinci dan jelas agar para pelamar mengetahui kualifikasi yang dituntut oleh lowongan kerja tersebut.

\section{Kinerja}

Kinerja karyawan dalam periode waktu tertentu perlu dievaluasi atau dinilai karena penilaian terhadap kinerja karyawan merupakan bagian dari proses staffing, yang dimulai dari proses rekruitmen, seleksi, orientasi, penempatan, pelatihan dan proses penilaian kerja, Alwi (2001:177). Kenyataan dewasa ini menunjukkan masih relatif banyak organisasi atau perusahaan mengabaikan fungsi penilaian terhadap kinerja. Pengertian kinerja seringkali disamakan dengan prestasi kerja yaitu prestasi sesungguhnya yang dicapai oleh pegawai. Mangkunegara (2000) menyatakan bahwa peranan kinerja pegawai sangat penting didalam suatu organisasi, hal ini sangat berpengaruh terhadap kinerja karyawan keseluruhan. Kinerja adalah hasil kerja secara kualitas dan kuantitas yang dicapai oleh seorang pegawai dalam melaksanakan tugas sesuai dengan tanggung jawab yang diberikan kepadanya.

\section{METODE PENELITIAN}

\section{Objek Penelitian}

Penelitian merupakan kegiatan yang dilakukan untuk mendapatkan kebenaran atau fakta, yang dilakukan dengan 
mengumpulkan dan menganalisis data secara teliti, jelas, serta sistematis, dan dapat dipertanggungjawabkan atau dapat diuji kebenarannya. Objek penelitian dalam proposal ini adalah Pengaruh Proses Rekruitmen terhadap Kinerja Karyawan Pada PT. Andesit Lumbung Sejahtera Lampung yang beralamat di Jalan. Raya Trans Sumatera KM 33 Tanjungan Lampung Selatan. Penelitian ini akan dilaksanakan pada bulan Juni 2019 sampai dengan Bulan Agustus 2019

\section{Metode dan Teknik Pengumpulan Data}

Dalam penelitian ini jenis data yang diperlakukan adalah :

a. Data Primer, yaitu data yang dikumpulkan dan diperoleh dari PT. Andesit Lambung Sejaahtera Lampung. Metode ini adalah suatu tinjauan langsung (field research) yang langsung pada objek penelitian dengan mengambil langkah : Observasi, Interview, dan Kuesioner

b. Data Skunder, yaitu data penunjang yang diperoleh dengan cara mengumpulkan sumber data, baik dari literatur, majalah, buku-buku yang ada hubungannya dengan kepegawaian

\section{Sampel dan Populasi}

Populasi bukan sekedar jumlah yang ada pada obyek/subyek yang dipelajari, tetapi meliputi karakteristik/sifat yang dimiliki oleh subyek atau obyek itu. Jumlah karyawan PT. Andesit Lambung Sejahtera sebanyak 76 karyawan.

Berdasarkan observasi di PT. Andesit Lambung Sejahtera diperoleh data bahwa jumlah karyawan sebanyak 76 karyawan. Berdasarkan data tersebut penulis menetapkan sampel dalam penelitian ini akan menggunakan teknik total sampling dimana seluruh populasi berlaku sebagai sampel.

\section{Metode Analisis Data}

Untuk pengolahan data dalam bentuk tabulasi hasil jawaban responden kemudian dilakukan analisis data melalui metode analisis secara kualitatif dan analisis kuantitatif.

Analisis kualitatif adalah analisis yang menggambarkan secara rinci, dengan interpretasi terhadap data yang diperoleh melalui pendekatan teoritis. Data yang diperoleh dari hasil angket untuk masingmasing variabel menggunakan Skala Likert, dimana alternatif jawaban responden diberikan skor 1 sampai dengan 5, selanjutnya nilai-nilai dari jawaban responden dijumlahkan berdasarkan bobot nilai. Kemudian kriteria skor total menggunakan interval skor harapan/ideal dengan rumus interval sebagai berikut:

$$
I=\frac{N T-N R}{K}
$$

\section{Dimana:}

I $=$ Nilai interval

NT $=$ Nilai total skor harapan tertinggi

$\mathrm{NR}=$ Nilai total skor harapan terendah

$\mathrm{K}=$ Jumlah alternatif jawaban

Analisis kuantitatif ialah metode analisis dengan angka-angka yang dapat dihitung maupun diukur, dan dalam prosesnya menggunakan alat bantu statistik. Pengolahan data statistik dalam penelitian ini dengan menggunakan aplikasi program komputer atau software Statistical Product and Service Solution (SPSS) for Windows versi 17.

Uji validitas adalah suatu derajat ketepatan alat ukur penelitian tentang isi atau arti sebenarnya yang diukur (Umar, 2001: 127). 


$$
r_{x y}=\frac{N\left(\sum X Y\right)-\left(\sum X\right)\left(\sum Y\right)}{\sqrt{\left[N\left(\sum X^{2}\right)-\left(\sum X\right)^{2} \mid N\left(\sum Y^{2}\right)-\left(\sum Y\right)^{2}\right]}}
$$

Keterangan:

$r_{x y}=$ koefisien korelasi suatu butir/item

$\mathrm{N}=$ jumlah subyek

$\mathrm{X}=$ skor Proses Rekruitmen

$Y=$ skor Kinerja (Arikunto, 2012: 72)

Kriteria keputusan uji validitas, sebagai berikut:

1. jika $r$ hitung $>r$ tabel maka kuisioner valid

2. jika $r$ hitung $<\mathrm{r}$ tabel maka kuisioner tidak valid.

Analisis regresi linier bertujuan untuk memprediksi atau mengestimasi nilai variabel dependen apabila nilai variabel independen yang diketahui mengalami kenaikan atau penurunan. Adapun persamaan regresi linier adalah sebagai berikut :

$$
Y=a+b x+e
$$

Dimana:

$\mathrm{Y} \quad=$ Variabel dependen (Kinerja)
$\mathrm{X} \quad=\quad$ Variabel independen
$($ Rekruitmen)
$\mathrm{a} \quad=$ Konstanta
$\mathrm{b} \quad=$ Koefisien regresi
$\mathrm{e} \quad=$ Variabel lain yang tidak diteliti
atau dimasukkan dalam model

Uji $\mathrm{t}$ digunakan untuk menguji signifikansi hubungan antara variabel $\mathrm{X}$ dan $\mathrm{Y}$, apakah variabel $\mathrm{X}$ (rekruitmen) benarbenar berpengaruh terhadap variabel $Y$ (kinerja) secara individual atau parsial. Hipotesis yang digunakan dalam pengujian ini adalah:

1. Ha1: Ada pengaruh secara signifikan rekruitmen terhadap kinerja

2. Ho1 Tidak Ada pengaruh secara signifikan rekruitmen terhadap kinerja
Uji Koefisien Determinasi, Dimaksudkan untuk mengukur kemampuan seberapa besar variasi variabel bebas (independent) pada model regresi linier berganda dalam menjelaskan variasi variabel terikat (dependent) (Priyatno, 2008). Nilai Koefisien determinasi adalah antara 0 (nol) dan 1 (satu). Nilai $\mathrm{R}^{2}$ yang kecil (nol) berarti kemampuan variable bebas (rekruitmen) dalam menjelaskan variasi variabel terikat (kinerja) amat terbatas. Begitu pula sebaliknya, nilai (R2) yang mendekati 1 (satu) berarti variabelvariabel bebas memberikan hampir semua informasi yang dibutuhkan untuk memprediksi variasi variabel terikat.

\section{HASIL DAN PEMBAHASAN}

Data penelitian yang telah dikumpulkan kemudian diolah untuk menguji kualitas data berupa uji validitas dan reliabilitas.

\section{Uji Validitas}

Uji validitas dilakukan dengan membandingkan nilai $r$ hitung (untuk setiap butir pertanyaan dapat dilihat pada kolom corrected item-total correlations), dengan $r$ tabel dengan mencari degree of freedom $(\mathrm{df})=\mathrm{N}-\mathrm{k}$, dalam hal ini $\mathrm{N}$ adalah jumlah sampel, dan $\mathrm{k}$ adalah jumlah variabel independent penelitian. Jika $r$ hitung $>r$ tabel, dan bernilai positif, maka pernyataan (indikator) tersebut dikatakan valid

Berdasarkan hasil pengujian validitas dengan aplikasi SPSS rekapitulasi hasil pengujian validitas strategi proses rekruitmen adalah sebagai berikut :

Validitas Strategi proses rekruitmen

\begin{tabular}{|l|l|l|l|}
\hline $\begin{array}{l}\text { No Item } \\
\text { test }\end{array}$ & Nilai $\mathrm{r}$ hit & $\begin{array}{l}\text { Nilai } \mathrm{r} \\
\text { tabel }\end{array}$ & Keterangan \\
\hline 1 & 0.718 & 0.632 & Valid \\
\hline 2 & 0.879 & 0.632 & Valid \\
\hline
\end{tabular}




\begin{tabular}{|l|l|l|l|}
\hline $\begin{array}{l}\text { No Item } \\
\text { test }\end{array}$ & Nilai $\mathrm{r}$ hit & $\begin{array}{l}\text { Nilai } \mathrm{r} \\
\text { tabel }\end{array}$ & Keterangan \\
\hline 3 & 0.924 & 0.632 & Valid \\
\hline 4 & 0.800 & 0.632 & Valid \\
\hline 5 & 0.788 & 0.632 & Valid \\
\hline 6 & 0.718 & 0.632 & Valid \\
\hline 7 & 0.788 & 0.632 & Valid \\
\hline 8 & 0.598 & 0.632 & Valid \\
\hline 9 & 0.759 & 0.632 & Valid \\
\hline 10 & 0.912 & 0.632 & Valid \\
\hline
\end{tabular}

Sumber : Data Diolah, 2019

Penafsirkan hasil uji validitas, kriteria yang digunakan adalah Jika nilai $r$ hitung > $\mathrm{r}$ tabel maka item angket dinyatakan valid. Berdasarkan hasil uji validitas, angket strategi proses rekruitmen secara keseluruhan dinyatakan valid.

Berdasarkan hasil pengujian validitas dengan aplikasi SPSS rekapitulasi hasil pengujian validitas kinerja adalah sebagai berikut :

Validitas Kinerja (Y)

\begin{tabular}{|l|l|l|l|}
\hline $\begin{array}{l}\text { Item } \\
\text { test } \\
\text { hit } \quad \mathrm{N}\end{array}$ & $\begin{array}{l}\text { Nilai rai } \\
\text { tabel }\end{array}$ & Keterangan \\
\hline 1 & 0.829 & 0.632 & Valid \\
\hline 2 & 0.787 & 0.632 & Valid \\
\hline 3 & 0.872 & 0.632 & Valid \\
\hline 4 & 0.781 & 0.632 & Valid \\
\hline 5 & 0.832 & 0.632 & Valid \\
\hline 6 & 0.832 & 0.632 & Valid \\
\hline 7 & 0.710 & 0.632 & Valid \\
\hline 8 & 0.688 & 0.632 & Valid \\
\hline 9 & 0.861 & 0.632 & Valid \\
\hline 10 & 0.898 & 0.632 & Valid \\
\hline
\end{tabular}

Sumber : Data Diolah, 2019

Berdasarkan hasil uji validitas kinerja, maka item angket kinerja secara keseluruhan dinyatakan valid.

\section{Uji Reliabilitas}

Hasil perhitungan uji reliabilitas terhadap instrumen penelitian variabel strategi saluran distirbusi dan peningkatan kinerja menunjukkan adanya reliabel (kesesuaian) baik antara item pertanyaan maupun totalitas. Secara rinci diperlihatkan pada tabel berikut :

Hasil Uji Reliabilitas

\begin{tabular}{|l|l|l|}
\hline Variabel & $\begin{array}{l}\text { Cronbach } \\
\text { Alpha }\end{array}$ & Status \\
\hline $\begin{array}{l}\text { Strategi proses } \\
\text { rekruitmen }\end{array}$ & 0,947 & Reliabel \\
\hline Kinerja & 0,954 & Reliabel \\
\hline
\end{tabular}

Sumber : Data Diolah, 2019

Tabel di atas, menunjukkan bahwa cronbach's alpha total untuk variabel proses rekruitmen sebesar 0.947> 0,600, sedangkan cronbach alpha untuk variabel kinerja sebesar 0,954>0,600, jadi dapat dinyatakan bahwa seluruh kuisioner adalah reliabel.

\section{Regresi Linier Sederhana}

Hasil dari penghitungan statistik regresi linier sederhana pengaruh strategi proses rekruitmen terhadap peningkatan kinerja adalah sebagai berikut :

Hasil Perhitungan Regresi Linier Sederhana pengaruh proses rekruitmen terhadap kinerja

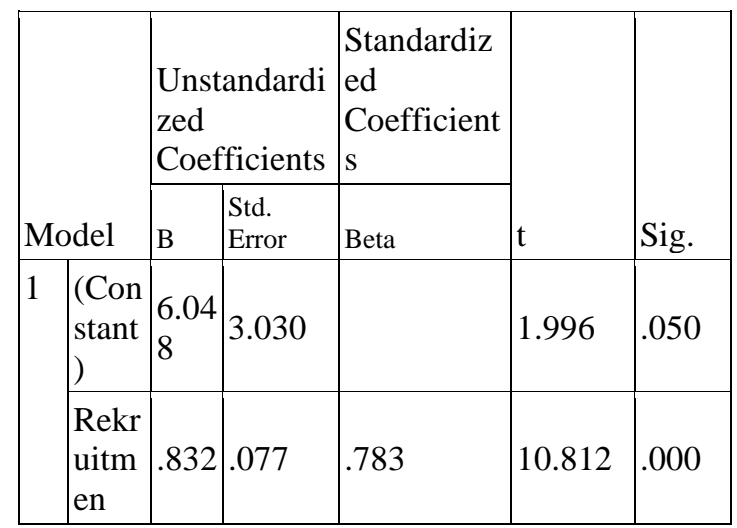

Sumber : Data Diolah, 2019

Hasil koefisien arah regresi antara proses rekruitmen terhadap kinerja sebesar 0.832 dengan konstanta sebesar 6.048, 
dengan demikian, persamaan regeresinya adalah Y (kinerja $=6.048+0.832 \mathrm{X}$ ( proses rekruitmen). Persamaan regresi tersebut terlihat bahwa pengaruh proses rekruitmen terhadap kinerja adalah searah (positif), hal tersebut ditunjukkan pada koefisien regresi dalam persamaan regresi tersebut yang menunjukkan angka positif sebesar 0,832 yang mengandung arti bahwa setiap kenaikan kinerja satu satuan akan diikuti dengan kenaikan proses rekruitmen sebesar 0,832 satuan.

\section{Uji Hipotesis}

Pengujian hipotesis pengaruh proses rekruitmen terhadap kinerja digunakan uji statistic t ( uji t) . Apabila nilai t hitung $>\mathrm{t}$ tabel maka Ho ditolak dan $\mathrm{Ha}$ diterima. Sebaliknya apabila nilai $\mathrm{t}$ htung < nilai t tabel maka Ho diterima dan Ha ditolak . Hasil pengujian hipotesis secara parsial dapat dilihat pada tabel berikut ini

Hasil Pengujian Hipotesis pengaruh proses rekruitmen terhadap kinerja

\begin{tabular}{|c|c|c|c|c|c|}
\hline \multirow[b]{2}{*}{ Model } & \multicolumn{2}{|c|}{$\begin{array}{l}\text { Unstandardized } \\
\text { Coefficients } \\
\end{array}$} & \multirow{2}{*}{\begin{tabular}{|l|} 
Standardize \\
d \\
Coefficient \\
s \\
Beta \\
\end{tabular}} & \multirow{2}{*}{$\mathrm{t}$} & \multirow[b]{2}{*}{ Sig. } \\
\hline & B & Std. Error & & & \\
\hline 1 (Constant) & 6.048 & 3.030 & & 1.996 & .050 \\
\hline $\begin{array}{l}\text { Rekruitme } \\
\text { n }\end{array}$ & .832 & .077 & .783 & 10.812 & .000 \\
\hline
\end{tabular}

Sumber : Data Diolah, 2018

Nilai $\mathrm{t}$ hitung variabel strategi proses rekruitmen yaitu 10.812 dengan konstanta 1.996 pada $t$ tabel dengan db 76 dan taraf signifikan 0,05 diperoleh 1.665 karena $\mathrm{t}$ hitung $>\mathrm{t}$ tabel atau $10.812>$ 1.655 maka Ha diterima. Signifikasi variabel proses rekruitmen adalah 0.000 yang berarti probabilitas 0.00 , karena probabilitas kurang dari 0,05 maka $\mathrm{Ha}$ diterima. artinya proses rekruitmen berpengaruh positif terhadap kinerja PT. Andesit Lumbung Sejahtera Lampung. Seberapa jauh variabel strategi proses rekruitmen menjelaskan variabel kinerja dapat dilihat dari nilai koefisien determinasi (R Square) pada tabel 4.8

Hasil uji Kooefisien Diterminasi

\begin{tabular}{|l|l|l|l|l|}
\hline $\begin{array}{l}\text { Mode } \\
1\end{array}$ & $\mathrm{R}$ & R Square & $\begin{array}{l}\text { Adjusted Rquare } \\
\text { Squar }\end{array}$ & $\begin{array}{l}\text { Std. Error } \\
\text { of the } \\
\text { Estimate }\end{array}$ \\
\hline 1 & $.783 \mathrm{a}$ & .612 & .607 & 2.11020 \\
\hline
\end{tabular}

Sumber : Data Diolah, 2019

Dari tabel di atas di atas diketahui bahwa hubungan antara proses rekruitmen dengan kinerja sebesar 0,783 berada pada taraf sedang. Sedangkan kontribusi (R Square) proses rekruitmen terhadap peningkatan kinerja sebesar 0.612 artinya sebesar $61,2 \%$ variasi perubahan proses rekruitmen mampu dijelaskan oleh variabel kinerja sedangkan sisanya sebesar 38,8\% lagi dijelaskan oleh variabel lain diluar dari variabel penelitian ini. Berdasarkan hasil pengujian hipotesis ini maka proses rekruitmen berpengaruh positif dan signifikan terhadap kinerja PT. Andesit Lumbung Sejahtera Lampung.

\section{KESIMPULAN DAN SARAN}

\section{Kesimpulan}

Berdasarkan hasil penelitian diperoleh kesimpulan sebagai berikut: Nilai $t$ hitung variabel strategi proses rekruitmen yaitu 10.812 dengan konstanta 1.996 pada $\mathrm{t}$ tabel dengan $\mathrm{db} 76$ dan taraf signifikan 0,05 diperoleh 1.665 karena $t$ hitung $>\mathrm{t}$ tabel atau $10.812>1.655$ maka Ha diterima. Signifikasi variabel proses rekruitmen adalah 0.000 yang berarti probabilitas 0.00 , karena probabilitas kurang dari 0,05 maka Ha diterima. artinya proses rekruitmen berpengaruh positif terhadap kinerja PT. Andesit Lumbung Sejahtera Lampung. hubungan antara proses rekruitmen dengan kinerja sebesar 0,783 berada pada taraf sedang. Sedangkan kontribusi ( $R$ Square) proses rekruitmen 
terhadap peningkatan kinerja sebesar 0.612 artinya sebesar $61,2 \%$ variasi perubahan proses rekruitmen mampu dijelaskan oleh variabel kinerja sedangkan sisanya sebesar $38,8 \%$ lagi dijelaskan oleh variabel lain diluar dari variabel penelitian ini. Berdasarkan hasil pengujian hipotesis ini maka proses rekruitmen berpengaruh positif dan signifikan terhadap kinerja PT. Andesit Lumbung Sejahtera Lampung.

\section{Saran}

1. Perusahaan harus lebih optimal dalam melakukan seleksi karyawan sesuai dengan persyaratan yang dicantumkan seperti surat lamaran, tes seleksi, proses seleksi dan tes kesehatan harus sesuai yang diharapkan perusahaan.

2. Perusahaan harus lebih efektif memilih karyawan yang memiliki kemampuan dan ketrampilan. Karyawan harus mengetahui segala kegiatan teknis terkait dengan lingkup pekerjanya, dapat memahami pekerjaan dengan baik, mempunyai ketrampilan sesuai dengan tuntutan kerja, mampu mengaplikasikan pengetahuan kerja yang mereka miliki, dapat mengelola dan mengatur pekerjaan dan selalu berupaya menyelesaikan tugas tanpa terjadi kesalahan.

\section{DAFTAR PUSTAKA}

Harsuko, 2016. Mendongkrak Motivasi dan Kinerja : Pendekatan Pemberdayaan SDM,. Malang: UB Press.

Ismiyanto, PC. S., M. Pd. 2015. Metode Penelitian. Semarang : FBS UNNES.

Kotler, Philip dan Amstrong. 2016. PrinsipPrinsip Manajemen. Edisi KeSebelas. Alih Bahasa Oleh Damos
Sihombing, MBA. Jakarta:Penerbit Erlangga

Mangkunegara, Anwar Prabu. 2015. Evaluasi Kinerja Sumber Daya Manusia. Bandung: Refika Aditama.

Mulyadi. 2015 Manajemen Sumber Daya Manusia. Jakarta :Penerbit In Media.

Nazir, Moh. 2015. Metode Penelitian. Bogor: Ghalia Indonesia.

Noor, Juliansyah. 2014. Metodologi Penelitian. Jakarta: Kencana Prenada Media Group

Pasolong, Harbani. 2017. Teori Administrasi Publik. Edisi Revisi. Bandung: Alfabeta .

Siagian, Sondang P. 2018. Manajemen Sumber Daya Manusia . Cetakan: 18. Jakarta : Penerbit Bumi Aksara.

Simamora, Henry. 2017. Manajemen Sumber Daya Manusia. Jakarta: STIE YKPN .

Singarimbun, Masri. 2017. Metode Penelitian Survey. LP3S - Jakarta.

Stephen, P.Robbins. 2018. Perilaku Organisasi. Alih Bahasa : Benyamin Molan. Edisi Ke Dua Belas. Jakarta. Penerbit : PT.Indeks, Kelompok Gramedia

Sutrisno, Hadi. 2014. Manajemen Sumber Daya Manusia. Edisi Kedua. Jakarta : Kencana Prenada Media Group.

Sugiyono. 2017. Metode Penelitian Administrasi. Bandung : Penerbit Alfabeta. 